\title{
PRIMARY HEALTH CARE RENDERED FROM MOBILE UNITS: CAN COMPUTERS HELP?
}

\author{
T Mc Donald, R D Chapman, J MacKenzie
}

\begin{abstract}
The object of survey was to assess which aspects of the nurses' work in mobile clinics could be computer ised with a beneficial effect on the quality of work. This paper is an analysis of how much time the nursing staff spent on various tasks. The results show that nurses are satisfied with their work, even in the face of difficult working conditions and a high workload. It was also found that computer and communications technology can promote greater efficiency in activities that represent $35 \%$ of a nurse's time.
\end{abstract}

\section{UITTREKSEL}

Die mikpunt van die opnane is om te bepaal watter aspekte van verpleegkundiges, in mobiele klinieke, se werk gerekenariseer kan word met verbeterde kwaliteit van werk as gevolg. Hierdie artikel ontleed die tyd wat verpleegkundige personeel aan 'n verskeidenheid van take spandeer. Die resultate toon dat die verpleeghundiges tevrede is met hulle werk, selfs in die lig van moeilike werksomstandighede en 'n hoë werkslading. Daar is ook bepaal dat rekenaar- en kommunikasietegnologie groter doeltreffendheid kan meebring in aktiwiteite wat $35 \%$ van die verpleegkundiges se tyd verteenwoordig.

\section{INTRODUCTION}

In regard to nursing activity, the small amount of time spend on direct patient care and the excessive administrative burden of nursing staff stands out various studies. Categorisation and quantification of nursing activities in an outpatient department was reported in Joseph (1990:21-22). The time allocated to various activities by registered nurses in a large metropolitan hospital was assessed by Barry et al (1990:40) and Hendrickson et al (1990:33). Hedtcke et al. (1992:19) did a study on how home health nurses spend their time. Concerning developing countries, Moidu et al. (1992:38) reports that community health workers at the peripheral health delivery units spend $40-50 \%$ of their working time compiling data for higher authorities. Ways to reduce this burden significantly so that nurses can do what they were trained for is a challenge, which to this day, has not been overcome satisfactorily.

The Provincial Administration of the Orange Free State (PAO) is responsible for rendering primary health care (PHC) services to the inhabitants of farms in the Orange Free State (OFS). These services are rendered by professional nurses and nursing assistants from 126 mobile clinics. The majority of farms are visited in a 6 to 12 week interval. Most of the people who use this service are black farm labourers and their families. The PHC service provided is health education, family planning, ante-natal care, post-natal care, child growth monitoring, immunisations, care of the elderly, treatment of minor ailments, promotion of optimal nutrition and treatment of endemic diseases such as tuberculosis and sexually transmitted diseases.

\section{OBJECTIVES}

Administration forms a large part of the professional nurse's work. This study was undertaken to obtain demographic information from the nurses, their conditions of work and their attitude towards work, to quantify these nurses' activities, to assess what aspects of their work can be computerised and to determine appropriate types of computerisation with its costs implications. A study of the activities involved in PHC as provided by mobile clinics and cars in a developing country is reported nowhere to the best of the authors knowledge. This paper deals with the first part of the study which is to assess and quantify the activities of nurses rendering a primary health care service out of a mobile unit.

\section{METIIODS}

The study was done in the rural areas of the Orange Free State. This province, which is approximately in the centre of the Republic of South Africa, comprises $10 \%$ of the surface area of the country. The province is divided into four hospital regions, north, south, east and west. A professional nurse and a nursing assistant, using a mobile clinic, are responsible for providing PHC services in designated areas.

Structured interviews were conducted with most of the senior nursing service managers to discover their views on issues surrounding the study. As a further preliminary step a day was spent with one mobile clinic to observe firsthand what the work in the mobile clinic entailed. Examples of all the different forms, cards and reports were collected for a detailed study of the information workload of the nurses.

A questionnaire was designed that reflected demographic details and a profile of typical activities for a nurse in charge of a mobile clinic as well for the area in which she works. Some questions indicating attitudes relating to her work and interpersonal relationships were included in the questionnaire. Several activities comprising a nurse's task were identified. The amount of time spent on each activity also was included in the questionnaire. A pilot study was conducted to eliminate unclear and confusing questions and to make certain that the activities covered a nurse's task.

Nurses visit their area during the first four days of the week and the fifth day they use for administrative purposes. A nurse's activities vary from day to day and week to week. Therefore, to find the amount of time spent on the different activities, the amount of time spent on each activity over a period of one month was studied. The nurses were asked what was the estimated amount of time spent on each activity. An activity log would have provided more reliable results, but the authors decided to use the above approach because of lack of time and the heavy workload of the nurses involved in the study.

The questionnaires were completed during the monthly in-service training sessions and most of the nurses therefore partook in the study Only those nurses who could not attend the training session on the specific day were excluded. The author was present during these sessions to ensure that everybody interpreted the questions similarly.

The data were processed on a Convex 
mini-computer, using SPSS (Statistical Package for the Social Sciences). Crosstabs mostly were used to obtain the numbers and percentages for the different categories. In one instance Pearson's Correlation Coefficient was calculated. F-tests were used to test for differences in means.

\section{RESULTS}

\section{Response rate}

Ninety-five questionnaires were completed This represents $80 \%$ of the professional nurses providing PHC services on farms. This is an excellent response rate and the conclusions therefore can be considered as representative of nurses working in this environment.

\section{Demographic information}

Only one $(1 \%)$ male nurse completed a questionnaire. The other personal details of the nurses consisting of age group, home language, qualifications and experience are reported in Table 1 . The predominant age group is 30 to 39 years with $40 \%$ of the nurses falling into this category. Sixty-five percent of the nurses fall into the age group of 30 to 49 years. The majority $(72 \%)$ of the nurses are Afrikaans speaking with Sotho $(16 \%)$ as the next highest. Only $7 \%$ of the nurses are graduates. The rest qualified with a diploma in general nursing. Most of these nurses have done one or more additional courses. The average number of years since completing their basic training is 17 years. In contrast the average number of years experience of PHC on farms is approximately three years. The last mentioned figure is solow because half of the nurses were former family planning nursing staff who started to render a comprehensive PHC service only from August 1991.

\section{Area Served}

Table 2 outlines the areas of reponsibility of the professional nurses. Sixty three percent of the nurses reported that they were responsible for rendering a service on 100 to 200 farms. In $55 \%$ of the cases the number of stopping points per area served is between 100 and 200 . Nearly half $(49 \%)$ of the areas served have at least 3000 residents. Approximately two-thirds of these people are served with PHC services. With every visit it was found that on average $20 \%$ of the farm inhabitants have moved away from the area served to unknown destinations. This creates problems with follow-up, statistics and administration. A further $17 \%$ is not present on the visiting day despite pre-arrangements. Nurses usually leave a visiting card giving the date of the next visit. Farms are visited six weekly in $68 \%$ of the cases. Six weeks between visits is ideal because it corresponds to the time between immunizations. Family planning return dates are also more easily ensured (12 weekly) but it is a long wait for child health, tuberculosis and certain other services.

\begin{tabular}{|lrrrrr|}
\hline \multicolumn{5}{c}{ Table 1. Demographic Information } \\
Age Group (years) & $20-29$ & $30-39$ & $40-49$ & over 50 & \\
& $12(13 \%)$ & $38(40 \%)$ & $24(25 \%)$ & $21(22 \%)$ & \\
Home language & Afrikaans & English & Sotho & Tswana & Xhosa \\
& $68(72 \%)$ & $6(6 \%)$ & $15(16 \%)$ & $4(4 \%)$ & $2(2 \%)$ \\
Qualifications & Diploma & Dip+1 & Dip+2 & Dip>2 & Degree \\
& $15(16 \%)$ & $33(35 \%)$ & $23(24 \%)$ & $17(18 \%)$ & $7(7 \%)$ \\
Years completed & $<=10$ & $<=20$ & $<=30$ & $>30$ & Average \\
& $31(33 \%)$ & $29(31 \%)$ & $21(22 \%)$ & $14(15 \%)$ & 16,98 \\
Months on PHC & $<=24$ & $<=48$ & $<=72$ & $>72$ & Average \\
& $60(63 \%)$ & $16(17 \%)$ & $5(5 \%)$ & $14(15 \%)$ & 38,83 \\
\hline
\end{tabular}

Table 2: Information about the area in which the nurses work

\begin{tabular}{|c|c|c|c|c|c|c|}
\hline No. of farms & $\begin{array}{r}<=100 \\
26(27 \%)\end{array}$ & $\begin{array}{r}<=200 \\
60(63 \%)\end{array}$ & $\begin{array}{l}<=300 \\
6(6 \%)\end{array}$ & $\begin{array}{r}>300 \\
3(3 \%)\end{array}$ & $\begin{array}{r}N \\
95\end{array}$ & $\begin{array}{r}\text { Average } \\
140\end{array}$ \\
\hline No. of stops & $\begin{array}{r}<=100 \\
11(12 \%)\end{array}$ & $\begin{array}{r}<=200 \\
51(55 \%)\end{array}$ & $\begin{array}{r}<=300 \\
26(28 \%)\end{array}$ & $\begin{array}{r}>300 \\
5(5 \%)\end{array}$ & $\begin{array}{r}N \\
93\end{array}$ & $\begin{array}{r}\text { Average } \\
183\end{array}$ \\
\hline No. of Residents & $\begin{array}{l}<=1000 \\
8(13 \%)\end{array}$ & $\begin{array}{r}<=2000 \\
13(21 \%)\end{array}$ & $\begin{array}{r}<=3000 \\
10(16 \%)\end{array}$ & $\begin{array}{r}>3000 \\
30(49 \%)\end{array}$ & $\begin{array}{r}N \\
61\end{array}$ & $\begin{array}{r}\text { Average } \\
3288\end{array}$ \\
\hline No. served with PHC & $\begin{array}{r}<=1000 \\
32(44 \%)\end{array}$ & $\begin{array}{r}<=2000 \\
13(18 \%)\end{array}$ & $\begin{array}{l}<=3000 \\
8(11 \%)\end{array}$ & $\begin{array}{r}>3000 \\
20(27 \%)\end{array}$ & $\begin{array}{r}N \\
73\end{array}$ & $\begin{array}{r}\text { Average } \\
2110\end{array}$ \\
\hline$\%$ moved & $\begin{array}{r}<=10 \\
38(44 \%)\end{array}$ & $\begin{array}{r}<=20 \\
22(25 \%)\end{array}$ & $\begin{array}{r}<=30 \\
13(15 \%)\end{array}$ & $\begin{array}{r}>30 \\
14(16 \%)\end{array}$ & $\begin{array}{r}N \\
87\end{array}$ & $\begin{array}{r}\text { Average } \\
20\end{array}$ \\
\hline$\%$ away & $\begin{array}{r}<=10 \\
45(51)\end{array}$ & $\begin{array}{r}<=20 \\
14(16 \%)\end{array}$ & $\begin{array}{r}<=30 \\
20(22 \%)\end{array}$ & $\begin{array}{r}>30 \\
10(11 \%)\end{array}$ & $\begin{array}{r}N \\
89\end{array}$ & $\begin{array}{r}\text { Average } \\
17\end{array}$ \\
\hline Weeks through area & $\begin{array}{r}<6 \\
5(5 \%)\end{array}$ & $\begin{array}{r}=6 \\
62(68 \%)\end{array}$ & $\begin{array}{r}<12 \\
4(4 \%)\end{array}$ & $\begin{array}{r}=12 \\
20(22 \%)\end{array}$ & $\begin{array}{r}N \\
91\end{array}$ & $\begin{array}{r}\text { Average } \\
7\end{array}$ \\
\hline
\end{tabular}

Table 3: Transportation Information

\begin{tabular}{|lrrrrr|} 
Vehicle type & $\begin{array}{r}\text { Motor } \\
\text { car }\end{array}$ & $\begin{array}{r}\text { Mobile } \\
\text { clinic }\end{array}$ & & & \\
& $37(39 \%)$ & $58(61 \%)$ & & \\
Kilometres/month & $<=1000$ & $<=2000$ & $<=3000$ & $>3000$ & Average \\
& $20(21 \%)$ & $59(62 \%)$ & $12(13 \%)$ & $4(4 \%)$ & 1533 \\
\hline
\end{tabular}

Table 4: Attitude information

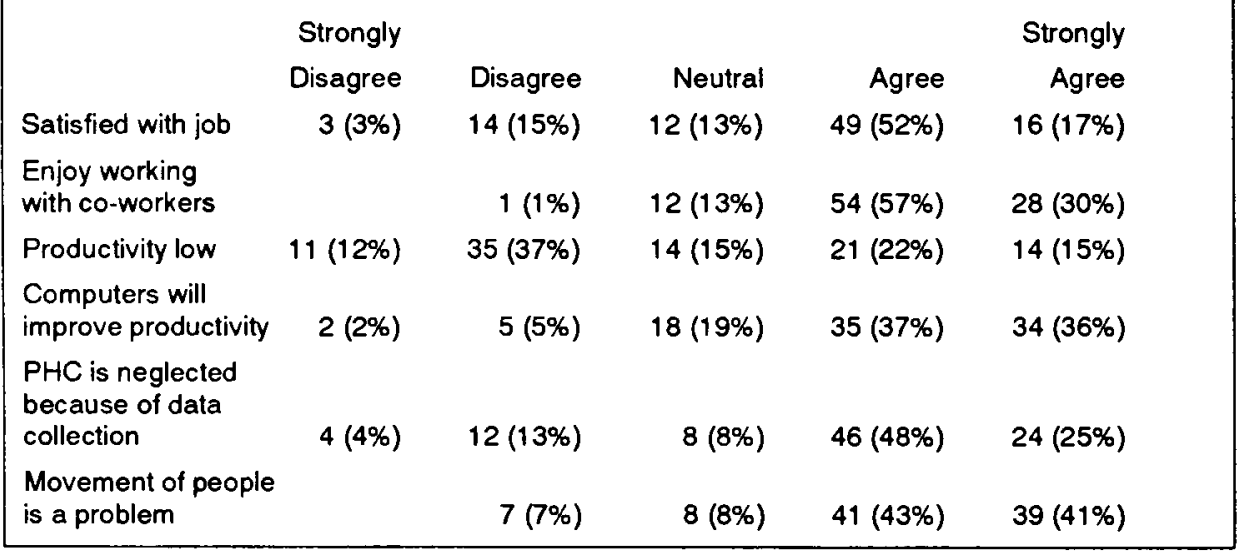

\section{Transportation}

Transportation details are provided in Table 3. At present only $61 \%$ of the nurses are issued with mobile clinics. The rest have to provide the PHC services from cars and the authors believe that this is particularly frustrating for the nurses because of the dusty surroundings, the unloading and loading of equipment at each visiting point and the absence of an examining table. A substantial amount of travelling is involved which is borne out by the fact that $83 \%$ of the nurses travel up to 2000 kilometres per month.

\section{Attitudes}

Table 4 details to what extent nurses agreed or disagreed with statements made conceming their work. Sixty-nine percent of the nurses are satisfied with their present job and $87 \%$ enjoy working with their co-workers; $49 \%$ of the nurses disagreed with the statement that their productivity level is below what it should be. 
Productivity was defined in this regard as the amount of time available for quality patient care. This reflects the fact that nurses are so busy with "other" things that direct patient care is neglected. The majority (73\%) agreed that the utilization of computers could improve productivity. This is substantiated by the next question which stated that PHC is neglected because of a preoccupation with data collection. Seventy-three percent of the nurses agreed with this statement and data collection is clearly one area where computers can play a major role. A contributing factor is the movement of people from the area which $84 \%$ of the nurses felt made information processing difficult.

\section{Activities}

The final and most important part of the study was finding out how the nurses spend their time. Table 5 outlines the definitions of activities of the nurse.

The amount of time spent on each activity during one month (185 hours) is reported in Table 6 . For this part of the analysis 26 cases had to be omitted because the number of hours did not add up to $\mathbf{1 8 5}$. Information from 69 respondents was analysed.

A univariate F-test revealed a significant difference between the means for four of the activities. These activities were Administrative work (significant on, 05 level), Stock control (significant on ,05 level), Training Students (significant on ,01 level) and Personal time (significant on ,05 level). The differences in the Personal times can be explained by different philosophies in the regions on the taking of tea times, lunches, etc. Students are not allocated evenly to all the regions for training and that explains the differences in that regard. The differences in the Stock control values can possibly be attributed to the distance from the main centre. The high mean value in the Eastern region for the administrative activity, which is the reason for the difference between the mean values, is difficult to explain.

Only the validity of Travelling time could be established by correlating it with the number of kilometres per month, which was an accurate figure. A correlation coefficient of 0,42 was obtained which was significant at the 0,01 level. Considering that the times provided by the nurses are estimates, the means for the four regions are remarkably close. Mean values of the four regions combined therefore provide a good indication on how nurses spend their time and these values will be used in the further analysis.

\section{DISCUSSION}

\section{Workload of the staff}

Not withstanding the vastly different sizes of farms in the Orange Free State it is clear that the majority of nurses visit 4 to 8 farms per day. Vast distances are travelled per day in

Table 5: Definitions of identified activities

Activities

Administrative work

Travelling time

Nurse-patient interaction

Stock control

Searching for information

Meetings

Loading/unloading/ maintenance of vehicle

Interaction with farmer/ school/other organisations

Giving lectures and talks

Community profile

Telephone

communications

in-house training and courses

Training students

Personal time

Definition

This represents the time spent on all paper work, i.e. paper work concerning the vehicle, supplies, patients and management.

This is the time spent driving the mobile clinic or car.

This is the accumulation of all the time spent on one-to-one interaction with the patients

This is the time spent managing (unpacking, counting, distributing, etc.) supplies.

This is the time spent searching through the hospital information system for information on patients from a particular area who were discharged.

The time spent in meetings.

Before leaving the area, supplies for the day must be loaded in the vehicle and on return the remaining supplies must be unloaded. In the case of a car, the loading/unloading can take place at each stopping point. The vehicle must be cleaned, and taken for service and repairs.

Liaison with the farmer concerning the workers on the farm, visits to farm schools and contact with other organisations like agricultural unions.

Educating the farm workers on health matters and addressing the public on various health topics.

Obtaining information from the community regarding drinking water, sanitation, eating habits, etc

All telephone conversations.

At least once a month nurses gather at a central venue for in-service training.

Nurses themselves provide training to students who work with the nurses for short periods of time to obtain practical experience.

Time spent on anything not related to a specific kind of work, for instance lunches, tea breaks, half day off, etc.

Table 6: Mean times (hours) spent on the activities over the four regions (percentages in brackets)

\begin{tabular}{|c|c|c|c|c|c|c|c|c|c|c|}
\hline \multirow{2}{*}{$\begin{array}{l}\text { ACTIVITY } \\
\mathrm{N}\end{array}$} & \multicolumn{2}{|c|}{ EAST } & \multicolumn{2}{|c|}{ NORTH } & \multicolumn{2}{|c|}{ WEST } & \multicolumn{2}{|c|}{ SOUTH } & \multicolumn{2}{|c|}{ Average } \\
\hline & & 21 & & 11 & & 17 & & 20 & & 69 \\
\hline Administrative & 51.1 & (28) & 35.3 & (19) & 36.6 & $(20)$ & 39.6 & (21) & 41.7 & (23) \\
\hline Travelling & 31.4 & $(17)$ & 28.5 & (15) & 38.5 & (21) & 34.7 & (19) & 33.6 & (18) \\
\hline Nurse-patient & 45.0 & (24) & 53.7 & (29) & 30.6 & (16) & 49.7 & (27) & 44.2 & (24) \\
\hline Stock control & 3.8 & (2) & 8.6 & (5) & 4.6 & (2) & 4.0 & (2) & 4.8 & (3) \\
\hline Searching info. & 5.5 & (3) & 5.0 & (3) & 6.5 & (3) & 6.8 & (4) & 6.0 & (3) \\
\hline Meetings & 4.9 & (3) & 5.5 & (3) & 7.0 & (4) & 4.0 & (2) & 5.3 & (3) \\
\hline Vehicle maint. & 6.6 & (4) & 6.1 & (3) & 6.7 & (4) & 8.8 & (5) & 7.2 & (4) \\
\hline Interaction & 5.7 & (3) & 4.0 & (2) & 8.4 & (5) & 6.1 & (3) & 6.2 & (3) \\
\hline Lectures/talks & 6.1 & (3) & 8.8 & (5) & 14.7 & (8) & 7.2 & (4) & 9.0 & (5) \\
\hline Community prof. & 4.2 & (2) & 5.8 & (3) & 3.9 & (2) & 5.3 & (3) & 4.7 & (3) \\
\hline Telephone comm. & 2.1 & (1) & 2.0 & (1) & 2.1 & (1) & 3.2 & (2) & 2.4 & (1) \\
\hline In-service & 8.6 & (5) & 10.0 & (5) & 8.9 & (5) & 10.0 & (5) & 9.3 & (5) \\
\hline Training students & 1.0 & (1) & 3.3 & (2) & 5.2 & (3) & 1.8 & (1) & 2.6 & (1) \\
\hline Personal time & 9.4 & (5) & 8.0 & (4) & 12.1 & (7) & 3.8 & (2) & 8.2 & (4) \\
\hline Total & 185.4 & & 184.6 & & 185.8 & & 185.0 & & 185.2 & \\
\hline
\end{tabular}

many cases and time spent travelling apparently bears out this statement. The available time for quality patient care is thus further reduced.

This could indicate the need for more personnel. Due to recruitment difficulties in outlying regions suitable personnel are not available readily. Reducing the workload by computerisation would alleviate the impact of unavoidable shortages of professional nurses in certain areas.

\section{Transient farm populations}

Continuity of care suffers seriously due to the migrant labour system operating on a majority of farms in the region. For example, vital 
follow up of tuberculosis sufferers and children at risk which could save lives, cannot be provided as new records are constantly being made out by health care providers in a area. Building a therapeutic relationship of trust is constantly lost.

The feasibility of computerization of records with a link up to a central data bank clearly needs to be studied to alleviate this problem.

\section{Use of time}

Nurses spent only $24 \%$ of their time on direct patient care. Such small amount of time spent on patient care is alarming when linked to existing manpower shortages. The administrative activity that consists mainly of completing forms and preparing reports account for $23 \%$ of a nurse's time. Record keeping is an integral part of nurse patient interaction since the nursing assessment forms the basis of all nursing intervention. This must be recorded as must all nursing intervention to ensure continuity of care and effective evaluation of progress. The frustration involved in repeating these comprehensive records when clients move is clear. The need for examination of other means of recording patient related data and easy retrieval is indicated.

Direct service rendering is what nurses are trained to do and this figure must be increased. One possibility is to decrease the times spend on other activities. Most of these tasks can easily be computerised.

\section{Application of computerisation}

Examples of activities that can be computerised are patient records and the identication of these records possibly using bar coding. Summarised information can be drawn from the system and for example lists of immunisation and tuberculosis defaulters can be printed. This will reduce administrative tasks and should improve nurses' effectivness and productivity. The nurses spend one day of the week in their office mostly doing administrative work. A well-designed computer system in the field will increase their productivity and allow them nurses an extra day in their area.

Other activities in which computer and communications technology can play a significant role is in the search for information concerning discharged patients from hospital. This can be accomplished by linking the computer in the nurse's office via modem to the information system of the hospital. Nurses have to travel to central locations for in-service training and meetings. Substantial savings in time can be achieved if all the nurses are linked in a computer network which provide computer conferencing and electronicbulletin board services. An electronic mail system can also save time with telephone communications.

In total $35 \%$ of a nurse's time lends itself to computerization with a subsequent reduction in travelling time. Exactly how this can be done will be reported in a future paper.

\section{REFERENCES}

BARRY C.T. AND GIBBONS L.K. (1990): Information Systems Technology: Barriers and Challenges to Implementation. Journal of Nursing Administration, Volume 20,(2), 40-42

HEDTCKE C.S., MACQUENN L. AND CARR A. (1992): How Do Nurses Spend Their Time? Journal of Nursing Administration, Vol. 22,(1), 18-24.
HENDRICKSON G.H., DODDATO T.M. AND KOVNER C.T. (1990): How Do Nurses Use Their Time? Journal of NursingAdministration, Vol. 20(3), 30-37.

JOSEPH A.C. (1990): Ambulatory Care: An Objective Assessment. Journal of Nursing Administration, Vol. 20,(11), 18-23.

MOIDU K., WIGGGERTZ O. AND TRELL E. (1992): Multi Centre Systems Analysis Study of Primary Health Care: A Study of Socio-Organizational and Human Factors. Int J Biomed Comput., Vol 30, 27-42.

Theo McDonaid,

D.Phil (Mathematical Statistics) UOFS Department of Computer Science University of the Orange Free State

Ronaid D Chapman M. Med (Community Health) UOFS Director Community Health POA

Joan MacKenzie

Senior Nursing Service Manager Primary Health Care POA 